\title{
THE TREND OF VOLUNTARY CONCILIATION AND ARBITRATION IN LABOR DISPUTES
}

\author{
By George M. Janes, Ph.D., \\ University of Washington, Seattle.
}

It is a popular fallacy that trade unions foment strikes and that striking is their reason for being. To this the trade unionist says: "Young and weak unions have many strikes; old and strong ones have few. If unions were mere striking machines, the opposite would be true." The importance of moderation is insisted upon by most labor leaders. Collective bargaining is the ultimate goal of nearly all trade unions, and to reach it not only organization but discipline is needed. Strikes are dangerous to the organization and costly. Hard experience has taught trade union officials that something more than enthusiasm is necessary to win a strike; and, while it may be true occasionally that a union thrives on opposition, a strike is not to be considered an end in itself. If the strike is lost, the better wages and conditions obtained by previous effort may be lost also. Experienced union officials, therefore, count the cost before entering on a struggle with the employer. The "get-richquick strike method," as it is called, is termed a failure. Paradoxical as it may seem, young and inexperienced unions often disintegrate after a strike is won, because it is easier to rely on promises than to continue the union and pay dues. But the retention of higher wages and better working conditions is usually contingent on the continuance of the union. The trade-union leader must not merely estimate the chances of success, but must also consider whether the ground won can be held. The law of the survival of the fittest has, therefore, brought about a more or less complete national control as opposed to local control of strikes in many unions, while in all there is unanimity of opinion concerning the value and need of organization and discipline. The domination of the national union over the local union usually means a conservative policy in the matter of strikes, as is brought out more fully by the writer elsewhere. ${ }^{1}$

${ }^{1}$ Janes, George M., The Control of Strikes in American Trade Unions, Johns Hopkins University Studies, Series 34, No. 3. 
Trade unions, however, vary in their composition and, like all other human institutions, have emotional and reasonable, radical and conservative men in their membership. Although it is true in the long run that age and closer organization bring about a conservative policy in the matter of strikes, the fact remains that trade unions vary from one another to a greater or less extent in point of view and policies pursued. The Industrial Workers of the World and the Western Federation of Miners, for instance, repudiate any form of arbitration or trade agreement with the employer and rely on direct action to attain their ends. The fruits of this policy are that the former organization is distinguished more for noise than for the real advancement of its few members, while the Western Federation of Miners is now on the rocks of disintegration. The Bridge and Structural Iron Workers, likewise, have relied on violence and the result is that many of their prominent members and former officials are now serving prison sentences. Another type exists, which has been termed the predatory one, whose officials use their position for extorting money for their own pockets from the employers-especially contractors - by threatening strikes or for terminating strikes. But the difference between trade unions is in reality no more than that which exists in the business world with the reliable merchant at one end and the "fence" receiving stolen goods at the other. The great mass of trade union members, like the great mass of business men, are trying to better their own conditions and have the same average ideas of ethics and justice as their neighbors. If this were not true, the use of conciliation and arbitration in labor disputes would be a vain dream.

Quite early in the development of American trade unionism it was realized by bitter experience that numerous strikes were disastrous and so rules were gradually adopted aiming at restriction of strikes to those disputes in which efforts at conciliation or offers of arbitration had failed to bring about an adjustment. This development is especially marked in those unions where the national union is dominant. The usual order of procedure in such unions in bringing about a strike is as follows: (1) the local union must exhaust all means of bringing about an adjustment of the difficulty; (2) the local union may then pass a strike vote which to be binding must be by secret ballot by a two-thirds or three-fourths vote of all members present, who have a standing of two or theee months or 
more; (3) the local union after this has been done must secure the approval of the national union, which generally means the national executive board, for the action taken; and (4) finally, only after exhaustive efforts on the part of the national officers or their deputies to bring about a settlement, can a strike be declared. A general vote of the entire membership, or that of the district affected, is taken before acting in a number of unions, especially the railroad brotherhoods. Even those unions in which local autonomy is the rule provide in some instances for arbitration by a provision in their constitutions that efforts for arbitration of disputes should be made before striking. The point of the procedure thus worked out is that time is allowed for a reasoned consideration of the dispute and for conciliation or arbitration with the employer instead of hasty, emotional, and ill-considered action at once. The trend in this direction seems to be quite general.

The sending of a national official to the scene of any trouble, or the "deputy system" as it is called, is a marked development of the principle of voluntary conciliation and arbitration. The function of the deputy is to go to the locality, investigate "the alleged matter of complaint," make an effort to adjust the matter, if possible, and report to the president and the executive board of the national union his conclusions and recommendations as to what course should be pursued. The agent or deputy is a representative of the national union, and his duties can be laid down only in a general way. As one trade union official has said:

The man on the ground representing the international union should use his best judgment; it does not matter whether he agrees with the local committee or not. If capable and experienced he is supposed to lead and not to follow. It is his duty to stand by the international union regardless of consequences, to protect the funds against waste and extravagance, and to maintain its reputation for a "square deal" with union manufacturers.

The deputy must be received by the local union, for if he is not permitted to perform his duties, strike benefits may be withheld by the national union and no further assistance granted. A strike entered into by a local union after refusing the offices of a national deputy would be illegal and would subject the local union to discipline such as a fine or loss of charter and strike benefits.

In all the unions that have adopted the "deputy system" it is regarded as important that the deputy should be on the ground 
before a strike is begun. It is required, therefore, that the members involved continue at work pending investigation and until a final decision has been reached. The rule has worked well; for any dispute can be more easily adjusted before an actual breach has occurred. President Martin Fox of the Iron Molders has observed that this rule "has strengthened the position of the union and proven beneficial in all cases." President Menger of the Operative Potters in an interview with the writer said:

If an international officer can get on the ground before a grievance has assumed large proportions and before either side has committed itself, a settlement can be more readily brought about than if the affair is allowed to go on.

A representative coming in from the outside is frequently able to compose differences which the parties themselves cannot settle. Those who are involved in a quarrel are not the best qualified to appraise its merits. Investigation by a party not previously involved is always helpful. The deputy acts as a mediator between the local union and the employer, and is often able to eliminate the local prejudice or personal feeling between the two parties. It is true that the deputy comes as a friend of the union; but he takes into account other considerations than the success of the local union. As a representative of the national union, he must consider whether the local union is justified in its demands, and whether the demands have been made in the proper spirit. All of these considerations make him a mediating element more or less independent of the local union. The Cigar Makers report that one of their deputies met the employer seventeen times before a settlement was finally effected. An editorial comment says:

The union will grow more rapidly in the future than it has in the past as soon as it is made clear that we as an organization have no desire to take an employer by the throat and make him do things regardless of whether competition, location and his business will permit.

The deputy usually remains on the ground in case of a strike and continues his efforts for an adjustment of the dispute, or he may be sent directly to take charge of a strike. A good deal of authority is given to the deputy in strike matters. His decisions are binding in some unions and subject to approval by the executive board or by general vote in others. If he is able to reach an agreement with the employer he can terminate a strike in some instances even if the 
local union objects. The deputy system, or some form of it, is now found in a large number of national unions. 'The tendency of the local unions is to turn more and more to the national officers in case of grievance, lockout, or strike; the work of the deputy has thus increased in quite a large measure and has resulted in the peaceful settlement of many disputes.

A word of caution is in order here: national unions vary in organization, discipline and financial resources and no general statement holds true of all of them. Some national unions, for instance, do not pay strike benefits and their local unions have complete autonomy in the matter of strikes. Even in these unions the advice of the national officers is often sought if not always followed. An indication of the trend of development is seen in the Hod Carriers' and Building Laborers' Union, which pays no strike benefits but which sends its president or a special organizer to direct strikes. Other national unions give their local unions the right to strike on their own initiative when only a small number of men is involved, or when, as in some unions in the building trades, the strike concerns a particular building or job, or when no financial assistance is expected. But even in these cases just cited, a national deputy is often sent by a number of national unions if a general strike is threatened. The source of control is in the power of the purse, the granting of strike benefits by the national union, and while it is true that a refractory local union occasionally defies national authority such action is coming to be an exception to the usual rule. "One 'Get Away' with holding up the parent body," to quote the expressive words of one union official, "does not mean that it can be done whenever the whim seizes a union or a number of unions." A radical membership, likewise, adds to the difficulties of control. 'The secretary of the Ladies' Garment Workers' Union, for instance, reports that in addition to ordinary difficulties "our immigrant members have their heads full of revolutionary stuff, which they read in the Jewish radical press, written by men who have little sympathy with our movement, understand it less, and to whom unions and strikes are only useful as a means of carrying on the 'class war.' To these the idea of adjusting labor disputes without constantly resorting to strikes is gall and wormwood." Another group of national unions includes the older and more highly organized unions which pay strike benefits and emphasize the necessity 
of discipline. In this group the deputy system has already brought about good results and it bids fair to be more effective in other national unions as time goes on.

The trend of voluntary conciliation and arbitration is seen in the procedure necessary before a strike can be called and in the development of the deputy system, but is more clearly indicated in the increasing use of trade agreements. The interesting point in this development is that there is no stoppage of work or strike pending investigation and settlement of any dispute. These agreements fall into two classes: the first where the agreement is directly between an employer's association and a national union, and the second where it is between a local union and a local employer. The Iron Molders, for instance, have had agreements with the Stove Founders' National Defense Association since 1891. Annual conferences with the manufacturers were begun by the Flint Glass Workers as the outcome of a strike settlement in 1888, but the method was not made a constitutional rule until 1891. The method of agreement of this last union was followed later by the Amalgamated Glass Workers, the Glass Bottle Blowers, and the Window Glass Cutters and Flatteners. The Operative Potters, after a disastrous strike in 1894, at their convention of the same year, first discussed the making of an agreement with the manufacturers, and after several years of discussion an agreement was entered into, to go into effect in 1900. This agreement has been renewed annually since then and no general strike has ensued. Since 1900 the Bricklayers' and Masons' Union has entered into agreements with contractors in various parts of the country providing that all differences that may arise be sent to headquarters for adjustment. Pending same, no strike can be entered upon by the members. Since 1901 there have been agreements between the American Newspaper Publishers' Association and the International Typographical Union, and later the Stereotypers', the Printing Pressmen, and the Photo Engravers' unions were included. The Coopers' International Union in 1905, the Granite Cutters' Union in 1907, and the National Association of Machine Printers and Color Mixers in 1909 entered into agreements with national employers' associations. A larger part of the membership of the United Mine Workers is now working under district agreements. The International Longshoremen's Association has also since 1900 entered into various agreements. The 
various railroad brotherhoods, such as the Locomotive Engineers, the Locomotive Firemen and Enginemen, the Railroad Conductors, the Railroad Trainmen, and the Railroad Telegraphers, beginning with the Locomotive Engineers in 1874, have made agreements with the railroads governing wages and working conditions; in case their local and general committees and national representatives fail to bring about an adjustment of difficulties recourse is usually had to the mediators designated in the Erdman (now the Newlands) Act. In case the mediation proceedings are ineffective, the dispute may go to arbitration. Leaving aside the railroad brotherhoods the interesting part of these agreements is the method provided for the settlement of disputes. The agreement between the Dredge Owners' Protective Association of the Great Lakes and the International Brotherhood of Steam Shovel and Dredgemen provides for the settlement of disputes in the following way:

In the event of a controversy arising between the parties hereto, or in the event of the men having a grievance, they shall continue to work and all such controversies and grievances will be settled if possible by the representative of the employer and the representative of the men. If such controversy or grievance cannot be settled by them, then it shall be arbitrated by choosing a third disinterested man upon whom the representative of the men and the representative of the employer may agree; if the representative of the men and the representative of the employer cannot agree, then the matter shall be submitted to the representative of the general organization of which he is a member, and the general manager, or his representative of the Dredge Owners' Protective Association of the Great Lakes, and if they cannot agree, then they shall choose a third disinterested party, and the said three shall constitute a Board of Arbitration and the decision of the majority thereof shall be final and binding, and all parties hereto shall abide thereby. It is expressly understood and agreed that said Arbitration Board shall meet within ten (10) days after the occurrence of the difference requiring arbitration has been submitted to them.

The arbitration agreement between the American Newspaper Publishers' Association and the International Typographical Union provides much the same method as the above. Local conciliation and arbitration are provided for and in case the local attempt fails or is not satisfactory an appeal may be made to National Board of Arbitration which consists of the three members of the executive council of the International Typographical Union and the three members of the special standing committee of the American Newspaper Publishers' Association, or their proxies. The finding of the majority of the national board is final and must be accepted as such 
by the parties to the dispute under consideration. No aid or support is given to the firm, employer, or local union refusing to abide by the decision.

Local agreements, or collective bargaining, without an arbitration clause, are and have been numerous. The interesting development is the increasing insistence that all local agreements shall contain provisions for arbitration. The bricklayers have been foremost in this policy. The New York agreement with the Mason Builders' Association came into existence in 1885 and contains a provision for arbitration. The same policy is found in the numerous local agreements entered into by the various unions connected with the building trades with builders' associations in leading vities. - The Bakery and Confectionary Workers, the Barbers, the Boot and Shoe Workers, the Brewery Workers, the Glove Workers, the Granite Cutters, the Horseshoers, the Machinists, the Pavers, the Steam Engineers, the Steam Fitters, the Tile Layers, and the Tobacco Workers, are some of the national unions which require their local unions to have an arbitration clause in their agreements. A typical arbitration clause of a local union of the Bakery and Confectionary Workers in Washington, D. C., is as follows:

All differences between Union No. 118 and the Washington Merchant Bakers' Association (or individual firm involved) that cannot be settled through the Business Agent of Union No. 118 shall be referred, first to three committees, one each from Union No. 118, the Grievance Committee from the Central Labor Union and one from the Washington Merchant Bakers' Association (or the firm involved). If these three committees cannot adjust the difficulty then arbitration shall be accepted as follows: Two disinterested parties are to be selected by the Washington Merchant Bakers' Association (or the firm involved), one member of the Grievance Committee of the Central Labor Union, and one disinterested person to be selected by Bakers' Union No. 118, these four selected to endeavor to adjust the matter in dispute, but in the event of failure to agree the four to select a fifth member of the committee on arbitration, and the decision of this committee to be final and to be accepted by all parties involved in the question.

These local agreements must usually be endorsed by the national union in order that as uniform a policy as possible be carried out. There seems to be a growing tendency according to statistics compiled by the New York State Department of Labor to insert arbitration clauses in local agreements.

Compulsory arbitration and even voluntary arbitration when it involves the calling in of only an outside party to adjust a diffi- 
culty is bitterly opposed by some trade-union officials. It is regarded as a broken reed to lean upon because the causes of strikes are according to these officials new desires and new demands which the rules of the past cannot satisfy. The question of wages and fewer hours is based on the problem whether or no the condition of the given business will justify the paying of higher wages or a reduction in the number of hours of work, and an outsider in the nature of things is said to know nothing about the relative merits of the case. Arbitration according to this view is regarded as the strongest weapon of the employer and the reason given in support of this theory is that such an arbitrator would be guided solely by the arguments of the employer concerning his ability to grant the demands. Labor organizations are advised to make sure that their demands are just and then to fight until they win them. Some unions rule out of the realm of arbitration any proposition to lengthen the hours of labor, and of course all stand firmly for the right to organize. The eight-hour day in the crafts where it exists was brought about by strikes, say trade-unionists, with the further statement that it could not have been obtained by arbitration. Another objection is that arbitration leads only to compromise and thus at times to no definite conclusions; but the answer to this is that all political and social progress of a permanent kind is based on compromise; a step at a time.

The complaint has been made that in recent years the strike has been commercialized and is now based more on the principle of expediency than on the principle of justice. The complaint contains some element of truth, but it is nearer the truth to say that the strike by means of trade-union organization and experience has been transferred from the realm of emotion to the realm of reason. Organization generally means fewer and not more strikes, conciliation and arbitration being used in the settlement of many disputes.

Strike statistics for the United States are available only until 1905. They show that there has been an increase since 1881 in the absolute number of strikes, but a slower increase, or even a decrease, in their number relatively to the growth of industry. The development seems to be in the direction of an occasional large strike as over against many small ones. A number of national officials say that so far as their organizations are concerned the adoption of a policy of conciliation and arbitration has reduced the number of 
strikes. A report of the growth of the Boot and Shoe Workers' Union says that the adoption of arbitration "marked the passing of the strike" in that organization. The Amalgamated Association of Street and Electric Employes, which has for its motto, "We are always ready to arbitrate our disputes," also reports a diminishing number of strikes on account of the adoption of arbitration. Too much cannot be made of a few cases, but there seems to be a consensus of opinion among both trade unionists and employers that the reasonable method of voluntary conciliation and arbitration has been very effective in settling disputes and in reducing the number of strikes.

Many of the sensible, intelligent and fair dealing trade unions are adopting the principle of voluntary conciliation and arbitration. Strikes, it is realized, mean industrial war and, as in all wars, the strongest side and not necessarily the right side wins. The right to strike is held to quite tenaciously but the tendency seems to be to substitute reason for force. But as it takes two to make a quarrel so it takes two to make an agreement. Between the arrogant, stubborn employer on the one hand and the unreasonable, turbulent labor leader on the other there is little to choose. "Nothing to arbitrate" means that there is no necessity for arbitration, and is based on the old principle that they should take who have the power, and they should keep who can. As a sagacious labor leader observed to the writer, "nothing to arbitrate means drunk with power."

Voluntary conciliation and arbitration is not a panacea-the human equation is still there-but it furnishes a means for bringing the employer and employes together and also a method for settling disputes. Mr. H. N. Kellogg, of the American Newspaper Publishers' Association after reviewing the history of the agreements with the unions of the printing trades, declares that "arbitration is the most sensible and the best method for settling labor disputes that has been developed up to this time." 